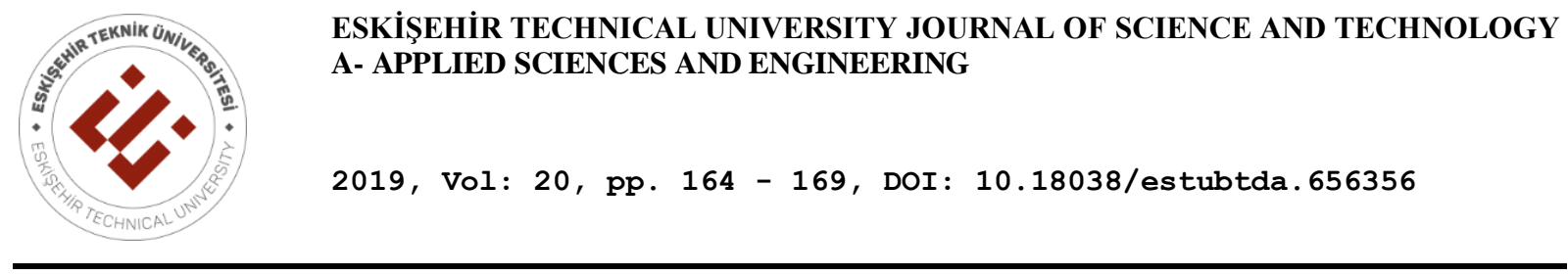

\title{
SUPRAMOLECULARTHERANOSTIC PLATFORMS GOES GREEN
}

\section{Ruken Esra DEMIRDÖĞEN ${ }^{1 *}$, Derya KILIÇ², Fatih Mehmet EMEN ${ }^{2}$, Ali İhsan KARAÇOLAK ${ }^{2}$, Muhammad Asım ALi ${ }^{3}$, Emine KUTLU ${ }^{2}$, Tuncay YEŞiLKAYNAK ${ }^{4}$, Göktürk AVŞAR ${ }^{5}$}

\author{
${ }^{1}$ Faculty of Science, Department of Chemistry, Çankırı Karatekin University, Çankırı, Turkey \\ ${ }^{2}$ Faculty of Arts and Science, Department of Chemistry, Burdur Mehmet Akif Ersoy University, Burdur, Turkey \\ ${ }^{3}$ National Institute for Biotechnology and Genetic Engineering, Faisalabad, Pakistan \\ ${ }^{4}$ Department of Chemistry Technology, Afşin Vocational School, Sütçü İmam University, TR46500, Kahramanmaraş, Turkey \\ ${ }^{5}$ Faculty of Arts and Science, Department of Chemistry, Mersin University, Mersin, Turkey
}

\begin{abstract}
World Health Organization projected the number of deaths due to cancer alone to be $\sim 13.1$ million by 2030 . To a certain extent conventional chemotherapy has been successful, but poor bioavailability, high-dose requirements, adverse side effects, low therapeutic indices, development of multiple drug resistance, and non-specific targeting have been severe limitations to its success. These limitations can be overcome via "theranostics" as it is precision medicine providing simultaneous diagnosis, targeted treatment and monitoring. Here the major actor is the drug -the therapeutic compound. It is importance to develop new green chemistries and technologies to produce supramolecular nanomedicines by employing appropriate inorganic and organic structures as theranostic platforms. SrMoO $4: \mathrm{Eu}^{3+}-\mathrm{MCM}-41-\mathrm{\gamma}-\mathrm{Fe}_{2} \mathrm{O}_{3}$ composite was synthesized and characterized via FT-IR and XRD techniques. XRD pattern of $\mathrm{SrMoO}_{4}: \mathrm{Eu}^{3+}-\mathrm{MCM}-41-\mathrm{\gamma}-\mathrm{Fe}_{2} \mathrm{O}_{3}$ composite shows the presence of $\mathrm{SrMoO}_{4}$ (PDF card No: 01-075-4312), $\gamma-\mathrm{Fe}_{2} \mathrm{O}_{3}$ (PDF card no: 00-013-0458) and amorphous $\mathrm{SiO} 2$ structures. The drug loading was investigated via TG systems. The amount of Ibuprofen loaded in the drug loaded $\mathrm{SrMoO}_{4}: \mathrm{Eu}^{3+}-\mathrm{MCM}_{-41-}$ $\mathrm{\gamma}-\mathrm{Fe}_{2} \mathrm{O}_{3}$ microstructures, which were calculated from the TG curves, was found to be $14 \%$. The release behavior of ibuprofen from $\mathrm{SrMoO}_{4}: \mathrm{Eu}^{3+}-\mathrm{MCM}-41-\gamma-\mathrm{Fe}_{2} \mathrm{O}_{3}-\mathrm{Ibu}$ was investigated in the PBS solution at $\mathrm{pH}=7.4$ and at $37{ }^{\circ} \mathrm{C}$ for $66 \mathrm{~h}$. In the first $8 \mathrm{~h}$., Ibuprofen is released on the surface absorbed and clinging to weak interactions. After than, Slow release of ibuprofen attached to the pores was observed.
\end{abstract}

Keywords: Theranostics, mesoporous $\gamma-\mathrm{Fe}_{2} \mathrm{O}_{3}$, Drug release

\section{INTRODUCTION}

The urgent need for targeted, safe, and efficient treatment of diseases gave birth to the rise of a new approach combining diagnosis and therapeutics with focus on patient-centered care. This new approach -theranostics- is concerned with providing unique predictive, preventive and successful personalized treatment protocol where the right drug would be offered to the right loaclity in the body of a given patient [1]. For this purpose, systems, which can selectively be "switched on" in the diseased locality, need to be designed and developed. These systems capable of avoiding problems that may arise due to cytotoxic effects of the drug on healthy cells and tissues mostly created by noncovalent interactions are called supramolecular systems [2]. These systems relying on weak and reversible forces (i.e., hydrogen bonds, hydrophobic forces, van der Waals forces, and metal-ligand coordination) play a key role in understanding biological processes, self-assembling systems as well as for constructing complex molecular machinery [3]. Although much effort is devoted to exploiting supramolecular metal-based structures such as supramolecular coordination complexes in the biomedical field still much effort is needed for using them as effective and efficient theranostic tools. The robustness and modular composition of supramolecular metal-based structures allows these systems to be modified with different functionalities that would enable imaging in cells via different modalities besides active targeting and stimuli-responsiveness [4].However, these systems should not load a toxic burden on the body and should also be eco-friendly for their preferrable availability. Therefore, supramolecular theranostics has to go green. In this respect, in this study $\mathrm{SrMoO}_{4}$ : Eu-

*Corresponding Author:rukenesrademirdogen@yahoo.com

Received: 13.10.2019 Published: 16.12.2019 
MCM-41- $\gamma-\mathrm{Fe}_{2} \mathrm{O}_{3}$ composite were synthesized. The composite was characterized via FT-IR and XRD techniques and their thermal properties were determined via DTA-TG. Drug releasing studies were carried out in PBS buffer solution.

\section{EXPERIMENTAL}

\subsection{Materials and Methods}

\subsubsection{Synthesis of MCM-41}

Typically, $0.6 \mathrm{~g}$ of n-cetyltrimethylammonium bromide (CTAB) was first dissolved in $400 \mathrm{~mL}$ of deionized water. Then $3.5 \mathrm{~mL}$ of $2 \mathrm{~mol} / \mathrm{L} \mathrm{NaOH}$ was added to the solution, followed by adjusting the solution temperature to $80{ }^{\circ} \mathrm{C}$. Subsequently, $2.5 \mathrm{~mL}$ of TEOS was added dropwise to the above solution with vigorous stirring. The mixture was stirred for another $2 \mathrm{~h}$ to give rise to white precipitates. The obtained solid product was filtered, washed with deionized water and ethanol, and then dried in air. The dried sample was calcined at $550{ }^{\circ} \mathrm{C}$ for $1 \mathrm{~h}$.

\subsubsection{Sythesis of mesoporous $\gamma-\mathrm{Fe}_{2} \mathrm{O}_{3}\left(\mathrm{MCM}-41-\gamma-\mathrm{Fe}_{2} \mathrm{O}_{3}\right)$}

$\mathrm{Fe}\left(\mathrm{NO}_{3}\right)_{3}$ was dissolved in ethanol and MCM- 41 was added to solution and stirred in the sonic bath for $2 \mathrm{~h}$. After the fitration, the powder was dried at $100{ }^{\circ} \mathrm{C}$ and fired at $600-650{ }^{\circ} \mathrm{C}$ for $3 \mathrm{~h}$. The obtained MCM-41- $\gamma-\mathrm{Fe}_{2} \mathrm{O}_{3}$ was added to $10 \mathrm{M} \mathrm{NaOH}$ and heated to dissolve MCM-41 phase. The obtained mesoporous $\gamma-\mathrm{Fe}_{2} \mathrm{O}_{3}$ was washed and dried.

\subsubsection{Preparation of $\mathrm{SrMoO}_{4}: \mathrm{Eu}^{3+}-\mathrm{MCM}-41-\gamma-\mathrm{Fe}_{2} \mathrm{O}_{3}$ microstructures}

$0.38 \mathrm{~g}$ of $\mathrm{SrCO}_{3}$ and $0.066 \mathrm{~g}$ of $\mathrm{Eu}_{2} \mathrm{O}_{3}$ were dissolved with $3 \mathrm{~mL}$ of $\mathrm{HNO}_{3}$ and the solution was heated to $1 \mathrm{~mL}$ to remove $\mathrm{HNO}_{3}$ and $2 \mathrm{~mL}$ of water was added each time and reheated. Addition of water and heating continued until the $\mathrm{pH}$ reached 2-3. To the prepared mixture of $\operatorname{Sr}\left(\mathrm{NO}_{3}\right)_{2}$ and $\mathrm{Eu}\left(\mathrm{NO}_{3}\right)_{3}$, $0.5494 \mathrm{~g}$ of sodium sodium molybdate dihydrate and $0.846 \mathrm{~g}$ of citric acid dissolved in a mixture of 20 $\mathrm{mL}$ of water-ethanol (15:5) as chelating agent were added and the molar ratio of metal: citric acid was adjusted to 1:2. $0.2 \mathrm{~g} / \mathrm{mL}$ Polyethyleneglycol (PEG, molecular weight: $300 \mathrm{~g} / \mathrm{mol}$ ) was added to this mixture as crosslinker. After stirring the solution for $1 \mathrm{~h}$, the sol was obtained and stirring was continued by adding the previously prepared $\mathrm{MCM}-41-\mathrm{\gamma}-\mathrm{Fe}_{2} \mathrm{O}_{3}$ powders. The suspension was stirred for 3 hours and centrifuged to separate the liquid and solid phase. The resulting precipitate was dried at $100{ }^{\circ} \mathrm{C}$ for $1 \mathrm{~h}$. Then, the nanostructures of $\mathrm{SrMoO}_{4}: \mathrm{Eu}^{3+}-\mathrm{MCM}-41-\gamma-\mathrm{Fe}_{2} \mathrm{O}_{3}$ were prepared by firing at $700{ }^{\circ} \mathrm{C}$ for $6-10$ hours.

\subsubsection{Drug Loading Studies}

Drug loading studies were carried out with supercritical carbon dioxide $\left(\mathrm{scCO}_{2}\right) .1 \mathrm{~g}$ of $\mathrm{SrMoO}_{4}: \mathrm{Eu}^{3+}-$ MCM-41- $--\mathrm{Fe}_{2} \mathrm{O}_{3}$ and $0.8 \mathrm{~g}$ ibuprofen were dissolved in $10 \mathrm{~mL}$ of ethanol and they were placed in the vessel and were reacted with $\mathrm{scCO}_{2}$ at $200 \mathrm{bar}, 40{ }^{\circ} \mathrm{C}$ for 90 minutes. Then the vessel was allowed to cool to room temperature and the gas was released from the reactor from the valve on the vessel. Thus, the drug loaded microstructures were obtained. 


\subsubsection{In vitro drug releasing studies}

In vitro drug release study was carried out at $37{ }^{\circ} \mathrm{C}$ with Ibuprofen loaded $\mathrm{SrMoO}_{4}: \mathrm{Eu}^{3+}-\mathrm{MCM}-41-\mathrm{\gamma}^{-}$ $\mathrm{Fe}_{2} \mathrm{O}_{3}$ microparticles in phosphate buffered saline (PBS) with molar composition $\mathrm{Na}^{+} / \mathrm{K}^{+} / \mathrm{Ca}^{2+} / \mathrm{Mg}^{2+} / \mathrm{Cl}^{-} / \mathrm{HCO}_{3}{ }^{-} / \mathrm{HPO}_{4}{ }^{2-} / \mathrm{SO}_{4}{ }^{2-}(\mathrm{pH}=7.4)$ at ratio of $142.0 / 5.0 / 2.5 / 1.5 / 147.8 / 4.2 / 1.0 / 0.5$. $3.5 \mathrm{~mL}$. For each $3.5 \mathrm{~mL}$ volume of aliquot removed from the medium $3.5 \mathrm{~mL}$ PBS was added. The release profile of drug from the microparticles was monitored via UV-Vis spectrophotometric analysis at $273 \mathrm{~nm}$.

\section{RESULTS AND DISCUSSION}

\subsection{Structural Characterization Studies}

\section{FT-IR studies}

FT-IR spectra of the $\mathrm{SrMoO}_{4}: \mathrm{Eu}^{3+}-\mathrm{MCM}-41-\mathrm{\gamma}-\mathrm{Fe}_{2} \mathrm{O}_{3}$ and $\mathrm{SrMoO}_{4}: \mathrm{Eu}^{3+}-\mathrm{MCM}-41-\gamma-\mathrm{Fe}_{2} \mathrm{O}_{3}-\mathrm{Ibu}$ were taken in the range of $400-4000 \mathrm{~cm}^{-1}$. The absorption peak at $587 \mathrm{~cm}^{-1}$ could be related to the vibration of $\gamma \mathrm{Fe}-\mathrm{O}$ [5-8] and the other peaks at $454,632,795$ and $892 \mathrm{~cm}^{-1}$ are pure maghemite $\left(\gamma-\mathrm{Fe}_{2} \mathrm{O}_{3}\right)$. The broad band observed in the FT-IR spectrum in the range of about $2600-3800 \mathrm{~cm}^{-1}$ shows the asymmetric strecthing vibrations of the H-O-H $\left(3435 \mathrm{~cm}^{-1}\right)$ and $\mathrm{Si}-\mathrm{O}-\mathrm{H}\left(3700 \mathrm{~cm}^{-1}\right)$ groups. The band seen at $1632 \mathrm{~cm}^{-1}$ corresponds to $\mathrm{H}-\mathrm{O}-\mathrm{H}$ bending vibration in adsorbed water molecules. The peaks observed at $1087 \mathrm{~cm}^{-1}$ and $1228 \mathrm{~cm}^{-1}$ belong to the strecthing vibrations of siloxane (Si-O-Si) bridges. Bending vibration of Si-O groups is observed at $799 \mathrm{~cm}^{-1}$. In the FT-IR spectrum of Ibuprofen the peaks observed at 2950-2520,3060, 3470 and $1717 \mathrm{~cm}^{-1}$ are attributed to the stretching vibrations of the aliphatic $-\mathrm{C}-\mathrm{H}$, aromatic $\mathrm{C}-\mathrm{H}, \mathrm{O}-\mathrm{H}$ in the carboxylic acid, and the intense peak at $1717 \mathrm{~cm}^{-1}$ is attributed to the stretching vibration of $-\mathrm{C}=\mathrm{O}$ in the carbonyl. When the FT-IR spectra of the drug loaded and unloaded $\mathrm{SrMoO}_{4}: \mathrm{Eu}^{3+}-\mathrm{MCM}-41-\gamma-\mathrm{Fe}_{2} \mathrm{O}_{3}$ were compared it was seen that the peaks observed in the ibuprofen. $2957 \mathrm{~cm}^{-1}$ and $1514-1465 \mathrm{~cm}^{-1}$ ranges in drug loaded microstructures may be due to ibuprofen. The FT-IR results indicate that ibuprofen was successfully loaded in the microstructructures.

\section{XRD studies}

Low angle XRD and XRD powder diffraction pattern of $\mathrm{SrMoO}_{4}: \mathrm{Eu}^{3+}-\mathrm{MCM}-41-\mathrm{\gamma}-\mathrm{Fe}_{2} \mathrm{O}_{3}$ are presented in Figure 1 and 2. The reflections $\left(\begin{array}{lll}1 & 0 & 0\end{array}\right)$ and $\left(\begin{array}{lll}1 & 1 & 0\end{array}\right)$ observed at $2.5^{\circ}$ in the low angle XRD powder pattern indicate the regular mesoporous MCM-41 structure. The reflections $\left(\begin{array}{lll}1 & 1 & 2\end{array}\right),\left(\begin{array}{lll}0 & 0 & 4\end{array}\right),(2$

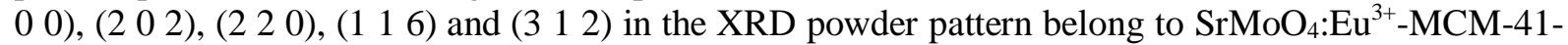

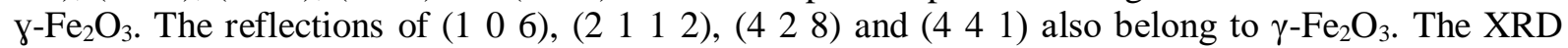
powder pattern indicated that the composite contains $\gamma-\mathrm{Fe}_{2} \mathrm{O}_{3}$ (PDF card no: 00-013-0458). In the XRD pattern, the $15-25^{\circ}$ broad peak belongs to the amorphous $\mathrm{SiO}_{2}$ structure. 


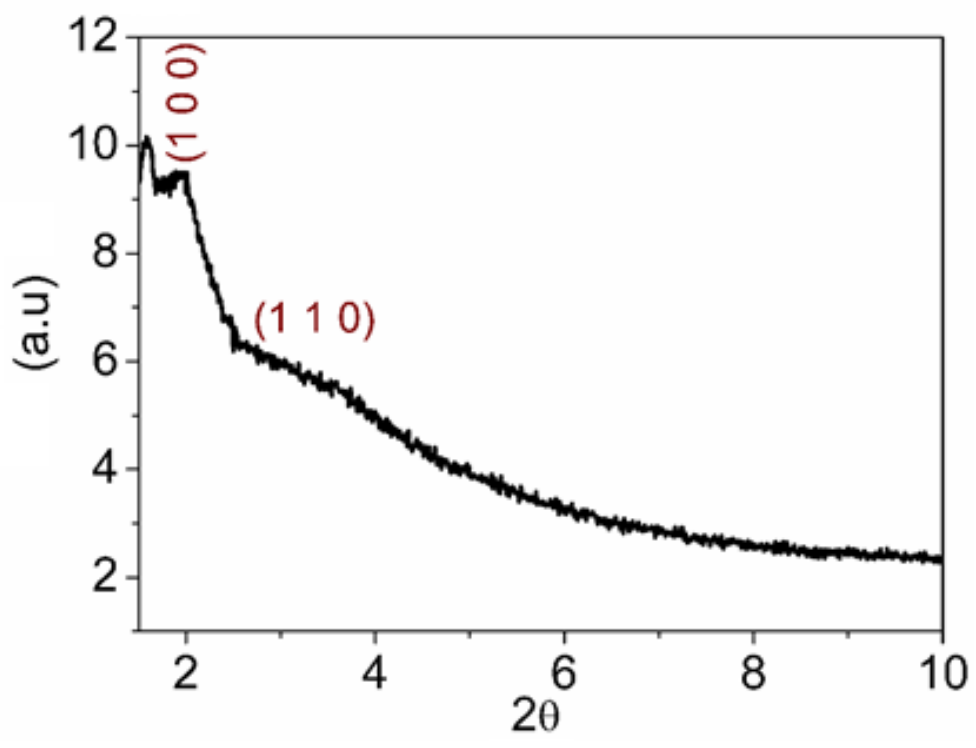

Figure 1. XRD Powder Pattern of MCM-41

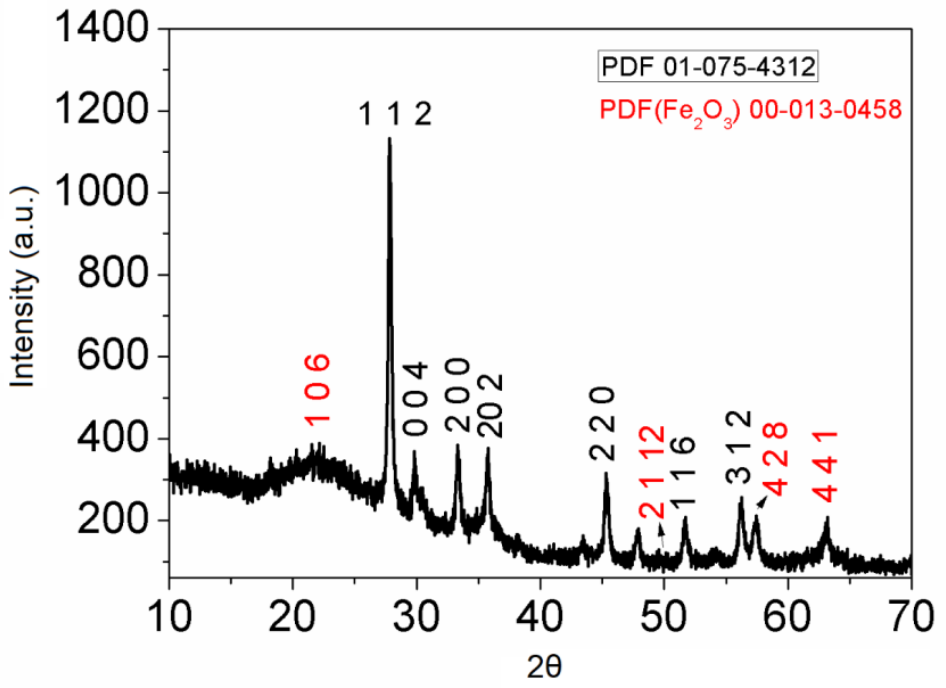

Figure 2. XRD Powder Pattern of $\mathrm{SrMoO}_{4}: \mathrm{Eu}^{3+}-\mathrm{MCM}-41-\mathrm{\gamma}-\mathrm{Fe}_{2} \mathrm{O}_{3}$

\section{Thermal Analysis of $\mathrm{SrMoO}_{4}: \mathrm{Eu}^{3+}-\mathrm{MCM}-41-\gamma-\mathrm{Fe}_{2} \mathrm{O}_{3}$}

The amount of Ibuprofen loaded in the drug loaded $\mathrm{SrMoO}_{4}: \mathrm{Eu}^{3+}-\mathrm{MCM}-41-\gamma-\mathrm{Fe}_{2} \mathrm{O}_{3}$ microstructures, which were calculated from the TG curves, was found to be $14 \%$. The TG curves of the microstructures are given in Figure 3. 


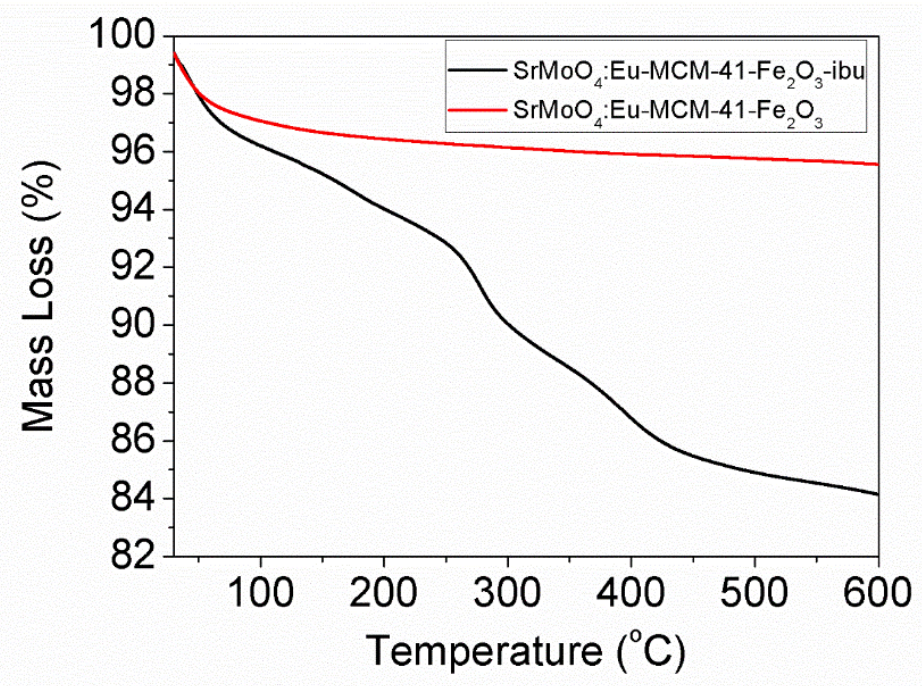

Figure 3. TG Curves of Ibuprofen loaded $\mathrm{SrMoO}_{4}: \mathrm{Eu}^{3+}-\mathrm{MCM}-41-\gamma-\mathrm{Fe}_{2} \mathrm{O}_{3}$ microstructure.

\section{Invitro Ibuprofen Releasing Studies}

Drug release profiles were determined from the plot of cumulative percentages of drug release against time. The release behavior of ibuprofen from $\mathrm{SrMoO}_{4}: \mathrm{Eu}^{3+}-\mathrm{MCM}-41-\mathrm{\gamma}-\mathrm{Fe}_{2} \mathrm{O}_{3}-\mathrm{Ibu}$ was investigated in the PBS solution at $\mathrm{pH}=7.4$ and at $37{ }^{\circ} \mathrm{C}$ for 66 hours as shown in Figure 4. In the first 8 hours, Ibuprofen is released on the surface absorbed and clinging to weak interactions. After than, slow release of ibuprofen attached to the pores was observed. Ibuprofen interacts with hydrogen in the pores with silanol ( $\mathrm{Si}-\mathrm{OH})$ groups. Wave swing is observed in the drug release profiles. This behavior is atrributed to non-uniform distribution of drug molecules in the layered matrices well besided diffusibility, number and thickness of layers [9].

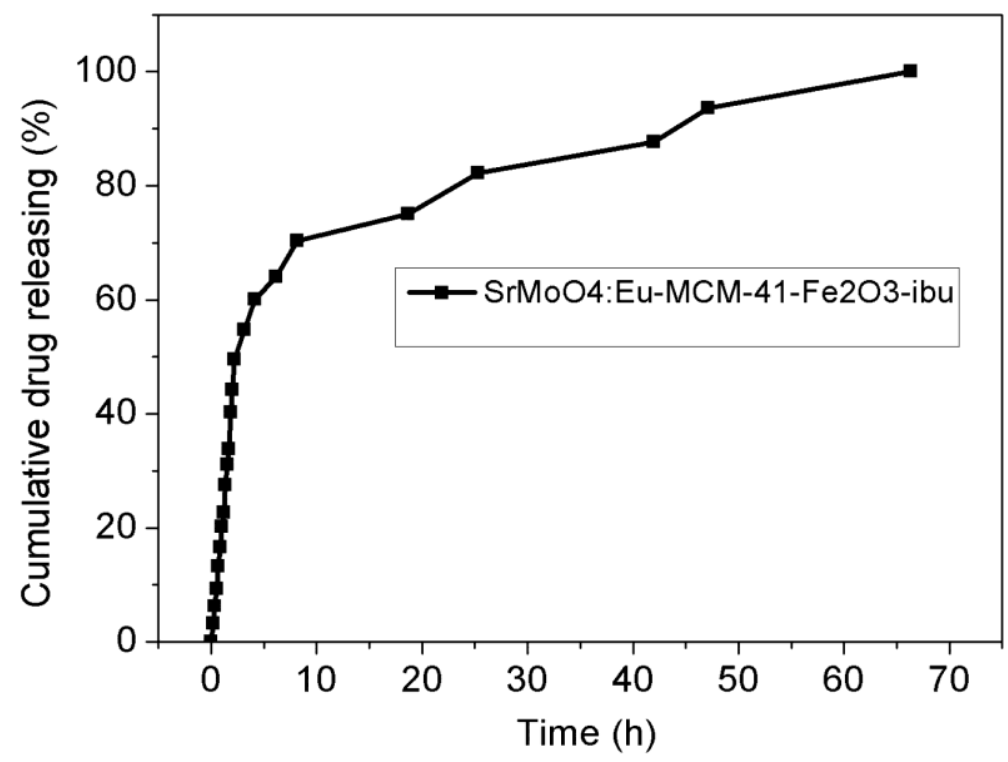

Figure 4. Cumulativedrugrelease $(\%)$ curves 


\section{ACKNOWLEDGEMENTS}

This study was supported by TÜBİTAK Under the Project number of $116 Z 402$ and supported by Burdur Mehmet Akif Ersoy University coordinator of scientific research projects under project number of 2017-YL-0472.

\section{REFERENCES}

[1] S. Jeelani, R. Jagat Reddy, T. Maheswaran, G. Asokan, A. Dany, B. Anand, Theranostics: A treasured tailor for tomorrow, J. Pharm. Bioallied Sci. 6 (2014) 6.

[2] H.-B. Cheng, Y.-M. Zhang, Y. Liu, J. Yoon, Turn-On Supramolecular Host-Guest Nanosystems as Theranostics for Cancer, Chem. 5 (2019) 553-574

[3] P. Szell, S. Zablotny, D.B.-N. communications,2019, Halogen bonding as a supramolecular dynamics catalyst, nature.com.

[4] A. Pöthig, A. Casini, Recent Developments of Supramolecular Metal-based Structures for Applications in Cancer Therapy and Imaging., Theranostics. 9 (2019) 3150-3169.

[5] V.E. Vorobeva, N.E. Domracheva, M.S. Gruzdev, A.V. Pyataev, Optical properties and photoinduced superparamagnetism of $\gamma-\mathrm{Fe} 2 \mathrm{O} 3$ nanoparticles formed in dendrimer, Mater. Sci. Semicond. Process. 38 (2015) 336-341.

[6] C. He, T. Sasaki, Y. Shimizu, N. Koshizaki, Synthesis of $\mathrm{ZnO}$ nanoparticles using nanosecond pulsed laser ablation in aqueous media and their self-assembly towards spindle-like $\mathrm{ZnO}$ aggregates, Appl. Surf. Sci. 254 (2008) 2196-2202.

[7] E. Darezereshki, M. Ranjbar, F. Bakhtiari, One-step synthesis of maghemite ( $\gamma$-Fe2O3) nanoparticles by wet chemical method, J. Alloys Compd. 502 (2010) 257-260.

[8] M. Jarlbring, L. Gunneriusson, B. Hussmann, W. Forsling, Surface complex characteristics of synthetic maghemite and hematite in aqueous suspensions, J. Colloid Interface Sci. 285 (2005) 212-217.

[9] S. Dash, P. Murthy, L. Nath, P.C.-A.P. Pharm, 2010, Kinetic modeling on drug release from controlled drug delivery systems, ptf.content-manager.pl. 